\title{
PEREMPUAN BALI DALAM LUKISAN GAYA KAMASAN KARYA PELUKIS MANGKU MURIATI
}

\author{
Ida Bagus Komang Sindu Putra \\ Institut Hindu Dharma Negeri Denpasar \\ sinduputra85@gmail.com
}

\begin{abstract}
This article discusses Balinese women in Kamasan style paintings by Mangku Muriati. The discussion in this article rests on two things, the psychobiographic aspects and the works of Mangku Muriati, which contain concepts and themes about gender issues. Biographically, Mangku Muriati growing and large experience in the Kamasan painting environment in her village, as well as the academic background obtained in college, as well as the professional and artistic professions that she practiced, have an influence on the way she understands gender which is then conveyed in her work. Furthermore, in his works, Mangku Muriati presents an expansion of themes from the puppet theme into everyday themes, especially about contemporary Balinese women and their role in social life. Mangku Muriati works contain statements about her attitude as a woman is looking at gender issues.
\end{abstract}

Keywords; Biography, Gender, Aesthetics, Kamasan Style Painting.

\begin{abstract}
ABSTRAK
Artikel ini membahas tentang perempuan Bali dalam lukisan gaya Kamasan karya Mangku Muriati. Pembahasan dalam artikel ini berpijak pada dua hal yakni aspek psikobiografi dan karyakarya Mangku Muriati yang didalamnya terkandung konsep dan tema-tema tentang persoalan gender. Secara biografi, pengalaman Mangku Muriati yang tumbuh dan besar dalam lingkungan seni lukis Kamasan di desanya, juga latar belakang pendidikan akademis yang diperoleh di perguruan tinggi, serta profesi kepemangkuan dan kesenimanan yang la lakoni memberi pengaruh pada cara pandangnya dalam memahami gender yang kemudian disampaikan dalam karyanya. Selanjutnya dalam karya-karyanya, Mangku Muriati menghadirkan perluasan tema dari tema Pewayangan menjadi tema-tema keseharian khususnya tentang perempuan Bali masa kini dan peran mereka dalam kehidupan sosial. Karya-karya Mangku Muriati mengandung pernyataan ihwal sikapnya sebagai perempuan dalam memandang persoalan gender.
\end{abstract}

Kata kunci ; Biografi, Gender, Estetika, Seni Lukis Gaya Kamasan 


\section{PENDAHULUAN}

\section{A. Latar Belakang}

Filosofi Hindu Bali, sejatinya menempatkan dan memandang posisi perempuan dan laki-laki dalam posisi yang setara. Bahkan perempuan memiliki peran yang sentral dalam kehidupan dan peradaban umat manusia. Secara konseptual tak ada perbedaan hirarki berdasarkan gender dalam pandangan filosofis Hindu Bali. Bahkan dalam pandangan Hindu Bali, Ida Sanghyang Widhi Wasa atau Tuhan atau Brahman menciptakan alam semesta dengan bermanifestasi sebagai Ardhanareswari yaitu gabungan dari sifat maskulin (laki-laki) dan feminim (perempuan). Hal ini tersurat dengan jelas dalam kitab Manawadharmasastra 1.32 yakni, "dengan membagi dirinya menjadi sebagian laki-laki dan sebagian perempuan (ardha -nari -iswari). la ciptakan viraja (alam semesta)". Dari teks Manawadaharmasastra ini kita dapat melihat demikian tingginya posisi ihwal kesetaraan gender dalam pandangan Hindu Bali bahkan proses penciptaan alam semesta inipun Tuhan mengambil perwujudan sebagai gabungan dari laki-laki dan perempuan. Tak ada subordinasi antar satu dan yang lainya. Tak ada dominasi laki-laki atas perempuan keduanya harus setara dan saling bersinergi.

Konsep Tri Murti yang diperkenalkan oleh Mpu Kuturan di Bali sejak abad kesebelas Masehi dengan pemujaan tiga Dewa utama yakni Brahma Wisnu Siwa didalamnya juga terdapat Tri Sakti yakni tiga perwujudan Dewi yakni Saraswati sebagai sakti dari Brahma, Laksmi sebagai sakti dari Wisnu dan Durga sebagai sakti dari Siwa. Ketiga Dewa dalam konsep Tri Murti tersebut tak akan dapat menjalankan fungsinya tanpa adanya peran dari Tri Sakti. Sehingga jika berkaca pada konsep ini perwujudan perempuan dipuja sebagai Dewi sebagai Sakti yang memegang peran sangat besar. Dalam konsep Siva Siddanta yang juga sangat berpengaruh di Bali sakti bukanlah "maya" tetapi faktor abadi yang penting, yang bekerjasama dengan "Siva" dimana tanpa ada kerjasama dengan-NYA, Siva tidak memiliki daya dan tak mampu menghasilkan keberadaan alam semesta yang tersembunyi dalam diri-NYA (Maswinara, 2006,292).

Pada praktik Agama Hindu yang berkembang sampai hari ini di dalam budaya masyarakat Bali, kehidupan keagamaan dijalankan dan ditopang oleh tiga kerangka dasar yakni Tatwa (filsafat), Susila (etika) dan Upakara (ritual). Aspek Upakara menjadi aspek yang paling terlihat karena didalamnya menghadirkan seperangkat artefak yang bersifat tangible (kebendaan) seperti pembuatan sarana Upakara berupa Bebantenan, maka perempuan memiliki peran yang sangat dominan didalam proses pembuatan 
Bebantenan tersebut. Hampir disetiap proses pembuatan Bebantenan tersebut perempuan selalu menjadi ujung tombak dan pihak yang paling berperan. Melalui tangan-tangan terampil para perempuan Bali aneka rupa sarana bebantenan yang tentu saja memiliki nilai filosofis tinggi sebagai simbol (niyasa) konsep dan filsafat (tatwa) yang didalam pengerjaanya didasari oleh etika (susila), banten juga sarat akan nilai-nilai estetika atau keindahan. Pada tataran inilah seni dan kebudayaan hadir dan menjadi karakteristik praktik-praktik agama masyarakat Bali dengan Hinduisme sebagai roh dari seni dan kebudayaan Bali. Sehingga tak salah kemudian jika Miguel Covarobias menyebut bahwa semua orang Bali adalah seniman.

Pendapat Covarobias ini dilatar belakangi oleh pengamatanya atas keseharian masyarakat Bali yang dekat dengan aktivitas kesenian. Dekatnya atau meleburnya masyarakat Bali dengan kesenian tentu tidak lepas dari landasan ideologis orang Bali yang memandang kesenian adalah bagian dari pengabdian (ngayah) terhadap sesuatu yang bersifat vertikal yakni berkeagamaan.

Dekatnya perempuan Bali dengan praktik praktik pembuatan bebantenan yang didalamnya mengandung nilai estetis secara alam bawah sadar telah pula memberikan pengalaman estetis terhadap perempuan Bali. Jika kita mengacu pada psikologi seni dari Carl Gustav Jung maka praktik ngayah membuat Banten bagi perempuan Bali dapat dikatakan sebagai sebuah arketipe. Menurut Jung arketipe adalah hasil dari pengalaman hidup yang berulang. Arketipe merupakan simbol dalam bentuk bawah sadar dan mengalami transformasi ketika menjadi sadar atau ketika sedang dirasakan, muncul dalam bentuk gambar dan emosi (Harbunangin, 2015,54).

Arketipe menjadi salah satu faktor yang berpengaruh bagi seorang seniman dalam proses kreatifnya. Dalam konteks perempuan perupa Bali praktik membuat sarana bebantenan ini dapat dikatakan menjadi arketipe yang juga berpengaruh dalam praktik dan proses kreatif mereka. Dunia seni rupa Bali mencatat hadirnya para perempuan perupa yang memberi warna dalam perkembangan seni rupa Bali melalui karya-karya mereka. Yang menarik untuk dikaji dan dicermati lebih dalam terkait dengan kehadiran perempuan perupa Bali ini adalah inwal bagaimana mereka bertumbuh di tengah-tengah kebudayaan Bali yang dijiwai oleh nilai nilai keagamaan Hindu Bali dengan segala praktik ritual yang menjadi ciri khas dari praktik-praktik keberagamaan di dalam masyarakat.

Peran yang multilapis tentu saja sangat terlihat dari keseharian para perempuan perupa Bali. Peran itu beririsan antara ekspresi individu sebagai perupa, peran dalam wilayah domestic, dan peran dalam ruang-ruang sosial kemasyarakatan Bali yang kental 
dengan praktik-praktik keagamaan komunal dengan praktik ritual yang dominan. Demikian kompleksnya peran perempuan perupa Bali sehingga kehadiran mereka dalam dunia seni rupa menjadi menarik dan penting untuk dicermati. Kehadiran mereka dalam dunia seni rupa hari ini telah membuktikan bahwa sekat-sekat gender, serta kompleksitas peran perempuan dalam kehidupan sosial, budaya, dan keagamaan Bali bukanlah sebuah halangan bagi mereka untuk meraih kesetaraan posisi dengan laki-laki perupa. Bahkan kompleksitas dan kekhasan adat, budaya serta praktik-praktik agama dan landasan luhur filosofis masyarakat Bali yang dijiwai oleh spirit Hindu Bali menjadi sumber inspirasi yang terus mereka gali dalam proses kreatif serta karya-karya mereka.

Mangku Muriati adalah salah satu perempuan perupa Bali yang menarik untuk dikaji dan dibaca kekaryaanya dalam perspektif gender. Aspek psikobiografi dirinya yang berada dalam irisan antara tanggungjawab menjadi seorang pemangku yang berperan sangat vital pada praktik ritual Agama Hindu Bali, khususnya di lingkungan masyarakat Banjar Siku Kamasan tempat ia tinggal. Serta karya-karyanya yang secara teknis tetap setia pada teknik tradisi gaya Kamasan sebagai akar budayanya dengan mengangkat tema tentang perempuan Bali dalam konteks kekinian. Seni lukis gaya kamasan merupakan hal yang sangat menarik untuk dicermati lebih jauh. Sehingga dalam artikel ini akan dibahas aspek psikobiografis serta kekaryaan Mangku Muriati dilihat dari aspek gender dan estetika. Karya-karya Mangku Muriati baik secara langsung maupun tidak langsung tentu saja akan berkaitan sangat erat dengan aspek psikobiografisnya.

\section{HASIL DAN PEMBAHASAN}

\section{A. Biografi Mangku Muriati}

Mangku Muriati lahir di Banjar Siku Kamasan, Kabupaten Klungkung pada tahun 1967. Seperti layaknya anak-nak yang lahir tumbuh dalam lingkungan masyarakat yang bergelut dan berkecimpung didunia kesenian khususnya melukis gaya Kamasan, sudah pasti Mangku Muriati juga terbiasa melihat dan melakoni aktivitas melukis gaya Kamasan ini sejak usia kanak-kanak. Gaya Kamasan adalah bentuk estetik dari lukisan yang berkembang di Desa Kamasan, tema-tema yang hadir pada seni lukis gaya kamasan adalah cerita pewayangan seperti wayang kulit, kebanyakan dari epos Mahabrata dan Ramayana. Sehingga secara awam sering pula disebut seni lukis wayang gaya Kamasan. 
Perkenalan Mangku Muriati dengan seni lukis gaya Kamasan terjadi dari pranata sosial primernya yakni dari lingkungan keluarga. la adalah anak perempuan Mangku Mura (1920-1999), salah satu tokoh pelukis gaya Kamasan. Sejak kecil ia mengikuti ayahnya melukis dengan mewarnai gambar-gambar lukisan khas wayang di Desa Kamasan. Bakat seninya semakin terasah ketika la sempat mengenyam pendidikan formal kesenirupaan di Program Studi Seni Rupa dan Desain (PSSRD) Universitas Udayana, Denpasar, Bali. Bersinggungan dengan dunia pendidikan seni akademis (modern) tak lantas memadamkan tekad dan minatnya untuk terus melukis dengan gaya Kamasan, setelah lulus kuliah la kembali melukis gaya Kamasan di rumahnya.

Jika dibandingkan dengan jumlah laki-laki yang menekuni seni lukis gaya Kamasan, jumlah perempuan yang tertarik menekuni bidang ini sangatlah sedikit. Hal inilah yang tampaknya juga menjadi motivasi bagi Mangku Muriati untuk memilih terjun ke dunia seni lukis gaya Kamasan ini. Sebagai perempuan, sejak kecil Mangku Muriati tidak pernah merasakan adanya posisi subordinasi atas dirinya dalam menekuni dunia seni lukis. la justru merasa mendapatkan dorongan dan semangat dari sang ayah yang begitu memperhatikan bakat dirinya. Mangku Muriati memiliki saudara laki-laki, yang juga menekuni seni lukis gaya Kamasan. Namun sang ayah tidak pernah membeda bedakan anaknya untuk mendapatkan akses belajar dalam menekuni seni lukis Kamasan.

Pada 1990 saat berusia 32 tahun, Muriati menjadi pemimpin ritual atau Pemangku di pura, tempat suci di tempat tinggalnya, Banjar Siku. Ini adalah sebuah tugas yang tak biasa dalam masyarakat Bali mengingat posisi Muriati sebagai perempuan dan masih memiliki saudara laki -laki. Biasanya dalam tradisi atau kebiasaan masyarakat seorang pemangku akan mewariskan gelar kepemangkuanya kepada anak laki-lakinya. Namun Mangku Mura, ayah Mangku Muriati justru memilih anak perempuanya yakni Mangku Muriati sendiri untuk mewarisi gelar dan tugas kepemangkuanya. Sejak menjalani tugas sebagai pemangku, maka Mangku Muriati menjalankan peran yang lebih kompleks lagi dalam kehidupan sosialnya maupun dalam kehidupan personalnya sebagai seorang pelukis. Dia harus membagi waktu antara urusan tugas kepemangkuanya dalam melayani umat yang ada di l;ingkungan banjarnya sebagai pemimpin ritual dan urusan kebutuhan berekspresinya secara personal sebagai perupa. Sebagai perempuan Mangku Muriati terbukti bisa menjalankan kedua peran tersebut secara proporsional.

Pada kekaryaanya juga demikian, Mangku Muriati tampaknya memilih mengembangkan dua kecenderungan kekaryaan. yang pertama adalah tetap setia 
mempertahankan tema-tema pewayangan maupun cerita malat atau panji dalam karya lukisnya seperti gaya lukis Kamasan pada umumnya. Namun pada kecenderungan kekaryaanya yang lain, Mangku Muriati berupaya mengembangkan tema-tema kekaryaanya pada persoalan sosial budaya masyarakat Bali hari ini. Termasuk tematema seputar kehidupan perempuan. Dalam beberapa karyanya misalnya, Mangku Muriati kerap menghadirkan tema-tema seputar kehiduipan perempuan Bali kini dengan segala karier dan profesinya. Seperti salah satu lukisannya yang berjudul wanita karier. Mangku Muriati menghadirkan sosok sosok perempuan dengan berbagai profesi seperti guru, polisi, tentara, tenaga medis dan lain sebagainya.

Pada ruang lingkup eksistensi dunia seni rupa, Mangku Murniati memilih tinggal dan berkarya di rumahnya Banjar Siku. Namun la tetap aktif melakukan pameran pameran ke berbagai tempat di Bali bahkan hingga ke luar negeri. Karya-karyanya tidak hanya dikoleksi oleh kolektor seni dari dalam negeri tapi juga di manca negara. Dalam era percepatan dan revolusi industry yang mengarah pada revolusi 4.0 teknologi informasi menjadi arus utama penggerak laju kehidupan manusia, Mangku Muriati dengan kesadaran membangun jejaring kerja yang luas oleh para relasi dan jaringanya juga memanfaatkan percepatan arus teknologi informasi ini dalam mengembangkan karier kesenirupaanya.

Karya-karyanya dipublikasikan di internet dan media sosial lainya oleh para kolega dan jaringan kerjanya. Hari ini kita tinggal mengklik nama Mangku Muriati dalam pencarian di internet maka segala informasi tentang kekaryaan, biografi, dan video dokumentasi tentang dirinya dapat dengan mudah kita akses. Mangku Muriati telah membuktikan bagaimana persoalan gender bukan batasan baginya untuk mengembangkan diri dalam dunia seni rupa. Dia juga telah membuktikan bahwa menjalankan tugas-tugas kepemangkuan yang terkait dengan agama, adat dan tradisi bukan halangan baginya untuk mengembangkan profesinya sebagai seorang perupa. la dengan segala kesadaran, komitmen dan tanggung jawabnya pada tugas sosial kemasyarakatan dan tanggung jawabnya sebagai perupa juga ikut serta dalam menyuarakan dan membangun kesadaran soal kesetaraan gender melalui karyakaryanya.

\section{Gender Dan Potret Perempuan Bali Dalam Karya Mangku Muriati}

Perkembangan dunia seni rupa hari ini adalah era seni rupa kontemporer. Dalam seni rupa kontemporer yang banyak dipengaruhi oleh pemikiran dan paradigma postmodernisme menempatkan karya seni rupa dalam pembacaan aspek artistik dan 
kebentukanya semata seperti dalam seni rupa modern. Konsep seni untuk seni yang menjadi spirit utama seni rupa modern mulai diperluas.seni bukan lagi membicarakan tentang dirinya sendiri, tapi seni kini menjadi alat untuk menyatakan sesuatu di luar seni , yakni kehidupan yang lebih luas.

Karya seni rupa kontemporer adalah karya yang memperlihatkan gagasan dan pemikiran sang seniman didalamnya yang terwujudkan dalam karya seni rupa. Berbagai isu dan tema tema sosial, politik, lingkungan, kemanusiaan, budaya ,spiritualitas, alam,hingga gender hadir sebagai isu yang dibicarakan dalam karya seni rupa. Seperti yang diungkapkan oleh kritikus seni rupa Sanento Yuliman bahwa ; "Seni masa kini adalah seni yang tidak dapat sepenuhnya dipahami tanpa menempatkannya dalam keseluruhan kerangka masyarakat dan kebudayaan." ( Yuliman, 2001; Saidi, 2008).

Bagi para perempuan perupa, persoalan gender menjadi persoalan yang kerap hadir pada karya -karya mereka sebagai bentuk pernyataan gagasan soal cara pandang mereka sebagai perempuan dalam memandang kondisi sosial masyarakat dimana persoalan ketimpangan gender masih kerap terjadi disebagian masyarakat kita. Kasuskasus kekerasan baik fisik maupun simbolik terhadap perempuan misalnya sesungguhnya bukan semata persolan perempuan tetapi soal kemanusiaan. Pada titik ini ideologi feminimisme bisa jadi salah satu jalan dalam pembacaan karya-karya para perempuan perupa yang menghadirkan persoalan keperempuananya dalam karyakaryanya. Marjorie Kramer (dalam Hilary Robinson, 2001) mengklasifikasikan seni feminis menjadi dua: yang tidak sadar dan yang sadar. Keduanya menjelaskan sudut pandang perempuan. Mereka bersifat simpati pada perempuan dan mereka secara social dapat dicacat, yakni mereka mengkomunikasikan sesuatu bahwa sang seniman meletakkan disana, dibangdingkan hanya sekadar menjadi sepenuhnya subjektif atau mengekspresikan diri sendiri.

Jika mengacu pada definisi dari seni feminis yang berpusat pada sudut pandang perempuan maka seni feminis adalah persoalan bagaimana sesungguhnya perempuan melihat persoalan dari sudut pandang mereka sebagai perempuan. Perempuan adalah subjek bukan semata objek dari karya seni. Sebagai subjek tentu saja perempuan perupa menjadikan karyanya sebagai medium untuk menyuarakan kegelisahan ataupun opini sang perempuan perupa atas lingkungan sosial mereka atau entitas di luar diri mereka yang terkait dengan posisi mereka sebagai perempuan di tengah tengah masyarakat.

Feminimisme juga sangat terkait dengan konsep gender. Barker mendefinisikan gender sebagai ; ide yang merujuk pada asumsi-asumsi serta praktik-praktik budaya 
yang mengatur kontruksi sosial lelaki, perempuan, dan hubungan-hubungan sosial diantara mereka. Konsep ini menjadi semakin jelas dipahami jika kita melawankanya dengan konsep seks sebagai formasi biologis tubuh. Mengingat gender adalah persoalan budaya dan bukan alam, maka ia tidak terlepas dari bagaimana lelaki dan perempuan terpresentasikan (Barker , 2014, 105). Jika melihat definisi yang diajukan Barker tentang gender maka konsep tentang gender sangat terkait dengan kebudayaan suatu masyarakat dalam memandang posisi laki-laki dan perempuan dalam suatu masyarakat.

Pada karya-karya Mangku Muriati terdapat dua karya yang menghadirkan konten pada persoalan gender didalamnya. Dua karya tersebut bercerita tentang peran perempuan dalam masyarakat. Dalam karya yang berjudul Wanita Karier dan Perang Kusamba, Mangku Muriati ingin menghadirkan narasi tentang bagaimana peran dan kontribusi perempuan Bali dalam masyarakatnya.

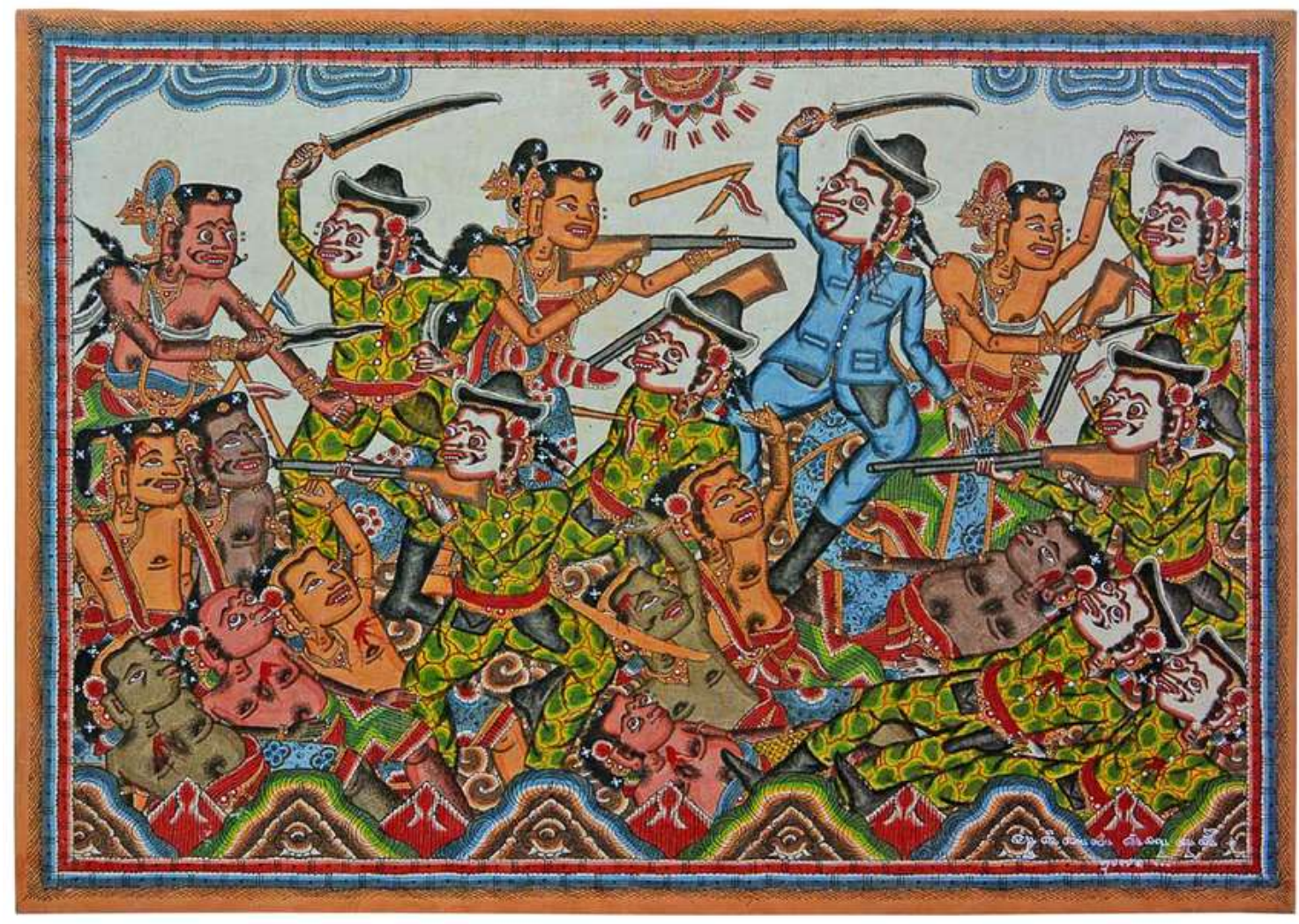

Gambar 01 ; Karya Mangku Muriati,“Perang Kusamba”

Foto: Ida Bagus Komang Sindu Putra, 2019 
Dalam karya yang berjudul Perang Kusamba, Mangku Muriati berangkat dari narasi historis tentang peristiwa perang Kusamba yang terjadi pada 24 - 25 Mei 1849. Perang antara rakyat Kusamba dan Belanda yang terjadi Kusamba itu adalah kisah heroik yang bercerita tentang keberhasilan rakyat Kusamba dan pasukan Pemating kerajaan Klungkung yang dipimpin seorang perempuan bernama Anak Agung Istri Kanya memukul mundur tentara Belanda. Dalam perang yang terjadi pada dini hari tersebut pimpinan pasukan Belanda Mayor Jendral A V Michles terbunuh ditangan Anak Agung Istri Kanya.

Dalam karyanya, Mangku Muriati melukiskan adegan pertempuran yang berangkat dari peristiwa historis tersebut dengan gaya lukis Kamasan. Biasanya karya lukis kamasan bertemakan kisah kisah Pewayangan ataupun malat yang umumnya bersifat mitologis namun Mangku Muriati dalam karya ini melakukan perluasan kemungkinan tematik dengan mengangkat peristiwa historis sebagai tema dalam karyanya. Dilihat dari unsur visual dan estetis karya ini menghadirkan adegan pertempuran antara lascar Pemating kerajaan Klungkung yang dibuat dengan gaya wayang lengkap dengan atribut pepayasan atau ornamen. Sedangkan tentara Belanda digambarkan dengan memakai atribut seperti tentara.

Secara komposisi karya ini tetap menghadirkan komposisi tumpukan tanpa adanya perspektif yang linier layaknya komposisi seni lukis gaya Kamasan pada umumnya. Adegan utama digambarkan ada di tengah tengah bidang gambar yakni adegan Anak Agung Istri Kanya yang sedang menembakkan senapan pusaka kerajaan Klungkung Ki Sligsig ke arah dada Mayor Jendral AV Michles yang ada di hadapan Anak Agung Istri Kanya. Pembagian bidang gambar tampak simetris kanan dan kiri dengan motif sinar rembulan di bagian tengah bidang gambar seolah membagi bidang gambar dalam dua bagian yang simetris. Teknik pewarnaan karya ini memaki teknik sigar warna layaknya karya - karya lukiosan wayang kamasan pada umumnya.

Sosok Anak Agung Istri Kanya digambarkan sebagai satu satunya figure perempuan yang terdapat dalam adegan lukisan tersebut. Jika kita membaca apa yang digambarkan oleh Mangku Muriati dalam karya ini maka secara makna konotatif dapat terbaca bahwa Mangku Muriati ingin menyampaikan bagaimana sisi-sisi heroism dan keberanian sosok Anak Agung Istri Kanya sebagaai perempuan untuk hadir dan terlibat dalam peperangan tersebut. la digambarkan sebagai satu satunya perempuan diantara para lelaki yang terlibat dalam pertempuran tersebut. Ada narasi inwal keberanian, heroisme dan jiwa kepemimpinan seorang perempuan yang ingin dihadirkan Mangku Muriati dalam karyanya. 
Jika dibaca dengan perspektif gender, maka karya Mangku Muriati seperti hendak menyatakan bahwa dalam sejarah perjuangan rakyat Bali melawan penjajahan Belanda, perempuan juga turut ambil bagian bahkan menempati posisi yang sentral sebagai panglima pasukan. Mangku Muriati seperti hendak melawan stigma tentang perempuan sebagai mahkluk yang lemah dan tak seberani laki-laki dalam menghadapi penjajahan. Sosok Anak Agung Istri Kanya dalam narasi historis perang Kusamba yang dilukiskan Mangku Muriati dalam karyanya adalah representasi dari semangat kepemimpinan, heroisme, dan kepahlawanan yang tak mengenal batas-batas jenis kelamin. Baik laki-laki maupun perempuan juga memiliki kontribusi dan peran yang sama dalam sejarah perjuangan bangsa. Spirit inilah yang hendak Mangku Muriati suarakan dalam karyanya.

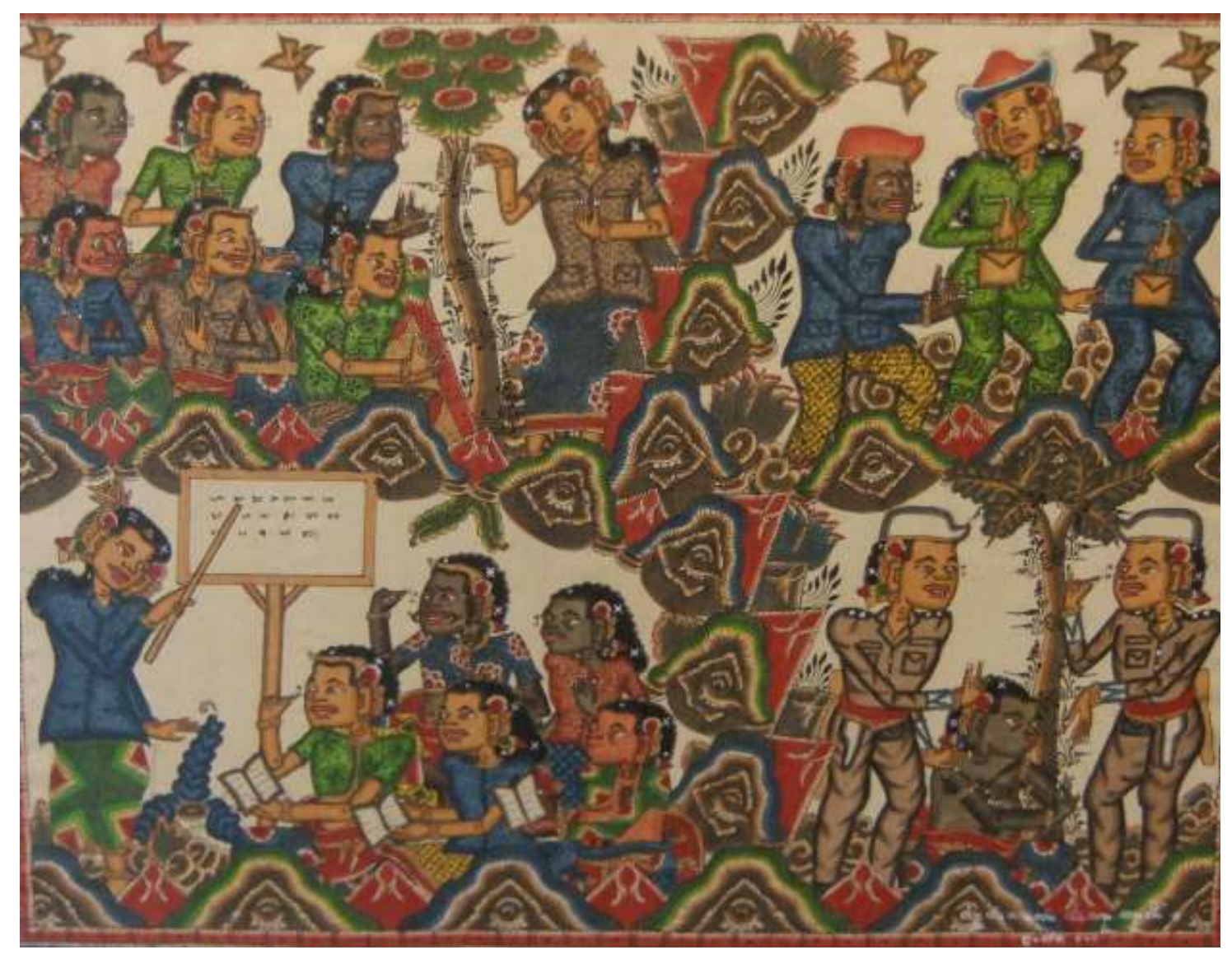

Gambar 2; Karya Mangku Muriati , "Wanita Karier" Foto: Ida Bagus Komang Sindu Putra, 2019

Dalam karya yang berjudul Wanita Karier, Mangku Muriati menggambarkan sosok sosok perempuan dalam berbagai profesi, mulai dari guru, tentara, polwan, dan 
pemimpin sebuah organisasi. Secara visual dan estetika objektif karya Mangku Muriati ini membagi bidang gambar dalam empat adegan yang tersusun secara simetris. Keempat adegan yang masing masing menggambarkan perempuan dalam profesi yang berbeda tersebut dibatasi dengan motif batu-batuan sehingga fragmen antar tiap tiap adegan terbagi dengan jelas. Secara komposisi karya ini juga menunjukkan sebuah komposisi yang simetris. Dengan pembagian ruang dibuat seimbang tiap tiap empat sudut bidang gambar terisi fragmen adegan.

Dalam konteks gender, karya Mangku Muriati ini adalah pernyataan dirinya dalam memandang posisi perempuan kini yang tak lagi berperan dalam urusan domestik, sebagai ibu rumah tangga yang mengurus urusan rumah tangga, memasak, merawat anak, hingga melayani suami. Perempuan kini sudah memiliki kesempatan yang sama untuk keluar dari ranah domestic menuju ranah public, mengambil peranperan dalam dunia pendidikan, pemerintahan, hingga pertahanan dan keamanan Negara. Kini, perempuan kuhusnya perempuan Bali ditengah tengah posisinya yang multi lapis sebagai ibu rumah tangga, bagian dari masyarakat adat, juga telah bebas dan leluasa mengembangkan potensi diri mereka masing masing dan menjalankan pilihan profresi itu secara professional dan bertanggung jawab. Tak ada lagi batasan batasan gender bagi perempuan Bali dalam memilih dan menjalankan profesinya.

\section{SIMPULAN}

Perempuan Hindu dalam tatanan masyarakat Bali kini, pada dasarnya sudah merepresentasikan kesetaraan gender, hal ini terlihat pada perjalanan hidup dan kekaryaan dari Mangku Muriati sebagai salah satu perempuan yang telah menjadi bagian dari revolusi industri 4.0 .

Barker, Chris. 2014. Kamus Kajian Budaya. Yogyakarta: PT. Kanisius.

Hardiman dan Luh Suartini, 2013. "Membaca Tubuh Gusti Ayu Kadek Murniasih:Representasi Seks. Kekerasan dan Kuasa Laki-laki”, Jurnal IImu Sosial dan Humaniora, Vol 2. No 1,2013. Hal.187-197.

Hasan, Asikin (ed.) 2001. Dua Seni Rupa, Sepilihan Tulisan Sanento Yuliman. Jakarta: Kalam. 
Maswinara, I Wayan. 2006. "Sistem Filsafat Hindu (Sarwa Dharsana Sanghara)".Surabaya ; Paramitha

Pudja, Gde.1978. "Manawa Dharma Sastra" . Departemen Agama Republik Indonesia

Robinson, Hilary. 2001. Feminism-Art-Theory, An Anthology 1968-2000. USA: Blackwell Publishers Ltd. 